\title{
REKONSTRUKSI SISTEM PEMIDANAAN TINDAK PIDANA KORUPSI DAN PENCUCIAN UANG DALAM PENDANAAN PEMILIHAN UMUM
}

\author{
July Esther \\ Fakultas Hukum Universitas HKBP Nommensen Medan \\ julyesther@uhn.ac.id
}

\begin{abstract}
Reporting of the campaign fund of the prospective liquid candidate one of the public question form of honesty over the acceptance of the illness of valid and couple. Funding in campaigner process in Indonesia elections became one of the highlights of the mode of criminal acts of corruption and money laundering. The Law of the Republic of Indonesia No. 7 of 2017 on general elections changed determines the deed that can be sentenced as a form of elections criminal in the case of election campaign funds that are not in accordance with the provisions of the legislation, i.e. the funding used for the campaign is derived from the corruption criminal act of bribery course or gratuities. Such acts are intentionally promising or giving money or other materials in return for and any person, group, company, and/or non-governmental entity that grants the election campaign funds exceeding the specified limit. The result of bribery or gratuities used for the funding of a general election campaign is indicative of a new mode of money-laundering crimes. The problem in this research is the reconstruction of criminal conviction in corruption and money laundering in general elections. Penalties for perpetrators of criminal acts of corruption and money laundering in general elections should apply the three laws through a cumulative indictment. The penal system as a reconstruction in conducting criminal burdens for perpetrators of corruption and laundering in funding general election activities.
\end{abstract}

Keywords: Criminalization, Corruption, Money Laundering, Elections

\begin{abstract}
Abstrak, Pelaporan dana kampanye pasangan calon merupakan salah satu informasi publik bentuk kejujuran atas laporan transaksi keungan yang valiud dan transparan. Pendanaan dalam proses kampaye pemilihan umum di Indonesia menjadi salah satu sorotan modus terjadinya tindak pidana korupsi dan pencucian uang. Undang-Undang Republik Indonesia Nomor 7 Tahun 2017 tentang Pemilihan Umum telah menentukan perbuatan yang dapat dipidana sebagai bentuk tindak pidana pemilihan umum dalam hal dana kampanye Pemilihan Umum yang tidak sesuai dengan ketentuan peraturan undang-undang, yakni pendanaan yang digunakan untuk kampanye berasal dari tindak pidana korupsi berupa suap ataupun gratifikasi. Perbuatan tersebut diantaranya adalah dengan sengaja menjanjikan atau memberikan uang atau materi lainnya sebagai imbalan dan setiap orang, kelompok, perusahaan, dan/atau badan usaha non pemerintah yang memberikan dana kampanye pemilu melebihi batas yang ditentukan. Hasil suap ataupun gratifikasi yang digunakan untuk pendanaan kampanye pemilihan umum inilah yang berindikasi sebagai modus baru terjadinya tindak pidana pencucian uang. Permasalahannya dalam penelitian ini adalah rekonstruksi pemidanaan pelaku tindak pidana korupsi dan pencucian uang dalam pemilihan umum. Pemidanaan bagi pelaku tindak pidana korupsi dan pencucian uang dalam pemilihan umum seyogyanya menerapkan ketiga undang-undang tersebut melalui surat dakwaan yang berbentuk komulatif. Sistem pemidanaan tersebut sebagai rekonstruksi dalam melakukan pemberatan pidana bagi pelaku tindak pidana korupsi dan pencucian dalam pendanaan kegiatan pemilihan umum.
\end{abstract}

Kata kunci : Pemidanaan, Korupsi, Pencucian Uang, Pemilu 


\section{Pendahuluan}

Perkembangan dunia yang ditandai dengan pesatnya kemajuan ilmu pengetahuan dan teknologi telah meningkatkan intensitas hubungan dan interdependensi antara negara dan juga mengakibatkan satu negara ke negara lain dilakukan dengan mudah dan cepat, maka dalam konteks penegakan hukum pidana, hal ini mengakibatkan pula perkembangan kejahatan dan modus operandinya semakin canggih sehingga penanggulangannya atau penegakannya diperlukan kerjasama antar negara yang satu dengan negara yang lain. ${ }^{1}$

Tindak pidana korupsi dan tindak pidana pencucian uang yang telah memiliki regulasi dalam bentuk undang-undang di Indonesia merupakan jenis tindak pidana transnasional yang terorganisasi sebagaimana termuan dalam Article 6 (1) dan Article 8 United Nations Convention Againts Transnational Organized Crime 2000, dengan unsurunsur tindak pidana sebagai berikut :

A. Article 6 (1) merupakan tindak pidana pencucian hasil tindak pidana dengan unsur-unsur tindak pidana :

a. Secara sengaja

1. Melakukan konversi atau pemindahan kekayaan hasil tindak pidana;

2. Mengetahui kekayaan tersebut hasil tindak pidana;

3. Tujuan menyembunyikan atau menyamarkan asal kekayaan yang tidak sah atau

4. Membantu seseorang yang terlibat tindak pidana asal tersebut untuk menghindari akibat hukum;

5. Melakukan penyembunyiaan atau penyamaran atas sifat dasar, sumber, dan lokasi;

6. Melakukan pelepasan, pemidanaan atau kepemilikan dari atau hak atas kekayaan hasil tindak pidana;

b. Tunduk pada sistem hukum

1. Perolehan, penguasaan atau penggunaan kekayaan

2. Partisipasi atau bekerja sama atau konspirasi untuk melakukan

3. Mencoba untuk melakukan dan membantu

4. Bersekongkol

5. Memfasilitasi dan membimbing tindak pidana yang terjadi

B. Article 8 merupakan Tindak Pidana Korupsi dengan unsur-unsur tindak pidana secara sengaja :

1. Melakukan janji, penawaran, atau pemberian kepada pejabat publik

2. Secara langsung atau tidak langsung

3. Keuntungan yang tidak semestinya

4. Untuk pejabat publik dalam tugas resminya atau orang atau badan lain

5. Agar pejabat bertindak atau menahan diri dalam pelaksanaan tugas resmi.

\footnotetext{
${ }^{1}$ Tim Kompendium Hukum tentang Kerjasama Internasional Di Bidang Penegakan Hukum, Laporan Akhir Kompendium Hukum Tentang Kerjasama Internasional Di Bidang Penegakan Hukum, Badan Pembinaan Hukum Nasional Kementrian Hukum dan Ham RI, Jakarta, 2012, hlm. 58-59.
} 
Undang-Undang Nomor 31 Tahun 1999 sebagaimana telah diubah dengan UndangUndang Nomor 20 Tahun 2001 tentang Pemberantasan Tindak Pidana Korupsi (UU Pemberantasan Tipikor) menjadi dasar hukum dalam pencegahan dan pemberantasan tindak pidana korupsi yang memuat pelaksanaan penyelidikan, penyidikan, dan pemidanaan pelaku tindak pidana korupsi. Perilaku kejahatan yang juga melibatkan motif-motif ekonomi dan juga berdimensi menimbulkan berbagai kejahatan lanjutan, adalah tindak pidana pencucian uang (Money Laundering).Menurut Sutan Remy Sjahdeini, Money Laundering adalah :

"serangkaian kegiatan yang merupakan proses yang dilakukan oleh seseorang atau organisasi terhadap uang haram, yaitu uang yang berasal dari kejahatan, dengan maksud untuk menyembunyikan data dan asal-usul uang tersebut dari pemerintah atau otoritas yang berwenang melakukan tindakan dengan memasukkan uang kedalam sistem keuangan, baik memanfaatkan jasa bank maupun nonbank. Lembaga-lembaga tersebut termasuk di dalamnya bursa efek, asuransi dan perdagangan valuta asing sehingga uang tersebut dapat dikeluarkan dari sistem keuangan yang halal". 2

Pemanfaatan lembaga keungan dalam kejahatan pencucian uang dapat berupa menginvestasikan dan memindahkan uang dari hasil tindak pidana seperti hasil uang hasil korupsi, suap, penipuan, kejahatan dibidang perbankan, pasar modal dan lainnya kedalam bentuk deposito, pembelian traveler cheque, saham, obligasi, reksadana dan instrumen keuangan lainnya. ${ }^{3}$ Semua harta kekayaan yang diduga berasal dari hasil tindak kejahatan yang disembunyikan atau disamarkan merupakan pidana pencucian uang. Tindak pidana pencucian uang tidak berdiri sendiri karena harta kekayaan yang ditempatkan, ditransfer, atau dialihkan dengan cara integrasi itu diperoleh dari tindak pidana, berarti sudah ada tindak pidana lain yang mendahuluinya (predicate crime). ${ }^{4}$

Menyikapi perkembangan modus operandi tindak pidana korupsi dan pencucian uang dalam rangka pemidanaan bagi pelaku, telah merambah kesistem pemerintahan dalam pesta demokrasi pemilihan umum baik pemilihan umum kepala daerah maupun pemilihan umum bagi Dewan Perwakilan Daerah (DPD), Dewan Perwakilan Rakyat Daerah (DPRD), Dewan Perwakilan Rakyat (DPR) dan Majelis Permusyawaratan Rakyat (MPR) serta Presiden/ Wakil Presiden. Perambahan tersebut berkaitan dengan pendanaan dana kampanye para pasangan calon kepala daerah/ Presiden/ Wakil Presiden maupun para Calon Legislatif yang telah dituangkan dalam pasal-pasal Undang-Undang Republik Indonesia Nomor 7 Tahun 2017 tentang Pemilihan Umum (UU Pemilu) beserta ketentuan pidananya.

${ }^{2}$ Sutan Remy Sjahdeini, Seluk Beluk Tindak Pidana Pencucian Uang dan Pembiayaan Terorisme, (Jakarta: Grafiti, 2004), hlm. 19.

${ }^{3}$ Yunus Husein, "Pembangunan Rezim Anti Pencucian Uang Di Indonesia dan Implikasinya Terhadap Profesi Akuntan" . Makalah Disampaikan Pada Forum Ekonomi Studi Akuntansi (Fiesta 2006) dan Temu Nasional Jaringan Masiswa Akuntansi Indonesia (Tn-Jmai), Diselenggarakan Oleh Fakultas Ekonomi Universitas Bung Hatta, Di Padang, 8 Mei 2006, hlm.1.

${ }^{4}$ Adrian Sutendi, Tindak Pidana Pencucian Uang, Ctk. Pertama ( Bandung: Citra Aditya Bakti, 2008), hlm.182. 
Pemidanaan pelaku yang memiliki dana kampanye berasal dari hasil tindak pidana korupsi yang berimbas indikasi adanya tindak pidana pencucian uang menimbulkan problematika dalam sistem pemidanaannya, karena terdapat tiga jenis tindak pidana yang berkaitan satu dengan yang lain yakni tindak pidana korupsi, tindak pidana pencucian uang, dan tindak pidana pemilihan umum. Masing-masing tindak pidana tersebut memiliki aturan tersendiri dalam sebuah undang-undang yang memuat ketentuan pidana sesuai dengan unsur-unsur tindak pidana yang telah terjadi. Rumusan masalah dalam penelitian ini untuk dikaji adalah urgensikah dilakukannya rekonstruksi pemidanaan pelaku tindak pidana korupsi dan pencucian uang dalam pemilihan umum?

\section{Metodologi Penelitian}

Penelitian hukum merupakan suatu kegiatan ilmiah, yang didasarkan pada metode, sistematika dan pemikiran tertentu, yang bertujuan untuk mempelajari satu atau beberapa gejala hukum tertentu dengan jalan menganalisanya. Kecuali itu, dapat juga diadakan pemeriksaan yang mendalam terhadap fakta hukum tersebut, untuk kemudian diadakan suatu pemecahan atas permasalahan yang timbul didalam gejala yang bersangkutan ${ }^{5}$. Tipe penelitian ini adalah penelitian hukum normatif yang mempunyai karakteristik sebagai ilmu yang bersifat preskriptif yaitu menjelaskan kebenaran yang seyogyanya melalui konsep-konsep hukum dan teori-teori hukum dengan melakukan analisis terhadap asasasas hukum, mengacu pada norma-norma hukum yang terdapat dalam peraturan perundang-undangan yang berkaitan dengan dengan judul penelitian ini.

Pendekatan masalah yang dipergunakan dalam melakukan penelitian ini adalah sebagai berikut:

1. Pendekatan perundang-undangan (Statute Aproach) dilakukan dengan menelaah semua undang-undang dan regulasi yang bersangkut dengan isu hukum. Selain menjadikan bahan, pendekatan juga dilakukan terhadap Undang-undang, diantaranya:

a) Undang-Undang Nomor 31 Tahun 1999 tentang Pemberantasan Tindak Pidana Korupsi Jo. Undang-Undang Nomor 20 Tahun 2001 Tentang perubahan atas Undang-undang Nomor 31 tahun 1999 Tentang Pemberantasan Tindak Pidana Korupsi.

b) Undang-Undang Nomor 8 Tahun 2010 tentang Pencegahan dan Pemberantasan Tindak Pidana Pencucian Uang.

c) Undang-Undang Republik Indonesia Nomor 7 Tahun 2017 tentang Pemilihan Umum

2. Pendekatan konseptual (Conceptual Aproach) merupakan pendekatan yang beranjak dari pandangan-pandanngan dan doktrin-doktrin yang berkembang di dalam ilmu hukum. Dengan mempelajari pandangan-pandangan dan doktrindoktrin dalam ilmu hukum, peneliti akan menemukan ide-ide yang melahirkan

\footnotetext{
${ }^{5}$ Soerjono Soekanto, Pengantar Penelitian Hukum, (Jakarta: UI-Press, 1984), hlm.42.
} 
pengertian-pengertian hukum, konsep-konsep hukum, dan asas-asas hukum yang relevan dengan isu yang dihadapi. ${ }^{6}$

Berdasarkan tipe penelitian ini adalah penelitian hukum normatif maka sumbersumber penelitian ini berupa bahan-bahan hukum primer dan bahan-bahan hukum sekunder ${ }^{7}$.

1. Bahan-bahan hukum primer yaitu merupakan bahan hukum yang bersifat autoritatif artinya bersifat otoritas. Bahan-bahan hukum primer dalam penelitian ini terdiri dari perundang-undangan, diantaranya:

a. Undang-Undang Nomor 31 Tahun 1999 tentang Pemberantasan Tindak Pidana Korupsi Jo. Undang-Undang Nomor 20 Tahun 2001 Tentang perubahan atas Undang-undang Nomor 31 tahun 1999 Tentang Pemberantasan Tindak Pidana Korupsi.

b. Undang-Undang Nomor 8 Tahun 2010 tentang Pencegahan dan Pemberantasan Tindak Pidana Pencucian Uang.

c. Undang-Undang Republik Indonesia Nomor 7 Tahun 2017 tentang Pemilihan Umum

2. Bahan-bahan hukum sekunder yaitu merupakan semua publikasi tentang hukum meliputi buku-buku teks, kamus-kamus hukum, dan jurnal-jurnal hukum, ${ }^{8}$ website serta tulisan lain yang berkaitan dengan penelitian.

Analisis atas bahan-bahan hukum dalam penelitian ini bersifat kualitatif, dengan mencari dasar ontologis dan Ratio Legis permasalahan pemidanaan tindak pidana korupsi, tindak pidana pencucian uang dan tindak pidana pemilu yang merupakan rangkaian perbuatan saling berhubungan untuk ditelaah dan dipaparkan dalam bentuk tulisan argumentatif sehingga jelas hubungan antara dua proposisi tersebut sesuai dengan hukum yang berlaku serta akhirnya diperoleh konklusi yang sistematis

\section{Pembahasan}

\section{Sistem Pemidanaan}

Salah satu cara untuk mencapai tujuan hukum pidana adalah pemidanaan, berupa tindakan memidanakan seseorang atau sekelompok orang yang telah melakukan tindak pidana atau perbuatan yang dianggap bertentangan dengan norma yang ada. Salah satu dasar pemidanaan adalah perlindungan hukum yaitu untuk tercapainya tujuan dari kehidupan penghidupan bersama berupa perlindungan hukum dilakukan melalui pemidanaan bagi mereka yang mengganggu tercapainya kehidupan yang diharapkan, agar

${ }^{6}$ Peter Mahmud Marzuki, Penelitian Hukum, (Jakarta: Prenada Media Group, 2015), hlm.135-136.

${ }^{7}$ Ibid, hlm. 141 .

${ }^{8}$ Ibid., hlm.181 
ketertiban hukum dapat tercapai. ${ }^{9}$ Hal-hal yang terkait dengan penormaan hukum pidana yaitu adanya pengaturan tentang: ${ }^{10}$

1. Tujuan Pemidanaan

a. Tujuan Pemidanaan adalah untuk :

1) Mencegah dilakukannya tindak pidana dengan menegakkan norma hukum demi pengayoman masyarakat;

2) Memasyarakatkan terpidana dengan mengadakan pembinaan sehingga menjadi orang yang baik dan berguna.

3) Menyelesaikan konflik yang ditimbulkan oleh tindak pidana, memulihkan keseimbangan, dan mendatangkan rasa damai dalam masyarakat;

4) Membebaskan rasa bersalah pada terpidana; dan

5) Memaafkan terpidana.

b. Pemidanaan tidak dimaksudkan untuk menderitakan dan merendahkan martabat manusia.

2. Pedoman Pemidanaan

a. Dalam merumuskan ancaman pidana dalam hukum pidana wajib dipertimbangkan:

1) Kesalahan pembuat tindak pidana;

2) Motif dan tujuan melakukan tindak pidana;

3) Sikap batin pembuat tindak pidana;

4) Apakah tindak pidana dilakukan dengan berencana;

5) Cara melakukan tindak pidana;

6) Sikap dan tindakan pembuat sesudah melakukan tindak pidana;

7) Riwayat hidup dan keadaan sosial dan keadaan ekonomi pembuat tindak pidana;

8) Pengaruh pidana terhadap masa depan pembuat tindak pidana;

9) Pengaruh tindak pidana terhadap korban atau keluarga korban;

10) Pemaafan dari korban dan/atau keluarganya; dan/atau

11) Pandangan masyarakat terhadap tindak pidana yang dilakukan.

b. Ringannya perbuatan, keadaan pribadi pembuat, atau keadaan pada waktu dilakukannya perbuatan atau yang terjadi kemudian, dapat dijadikan dasar pertimbangan untuk tidak menjatuhkan pidana atau mengenakan tindakan dengan mempertimbangkan segi keadilan dan kemanusiaan.

c. Seseorang yang melakukan tindak pidana tidak dibebaskan dari pertanggungjawaban pidana berdasarkan alasan peniadaan pidana, jika orang tersebut telah dengan sengaja menyebabkan terjadinya keadaan yang dapat menjadi alasan peniadaan pidana tersebut.

Berdasarkan tujuan dan pedoman pemidanaan tersebut maka ketentuan-ketentuan yang menyimpang dari ketentuan umum berlaku adagium "Lex specialis derogat legi generali", artinya peraturan atau ketentuan khusus mengesampingkan atau

9 Perencanaan Pembangunan Hukum Nasional Bidang Hukum Pidana dan Sistem Pemidanaan (Politik Hukum dan Pemidanaan ), Departemen Hukum dan Hak Asasi Manusia Badan Pembinaan Hukum Nasional Tahun 2008, hlm. 83.

${ }^{10} \mathrm{Ibid}, \mathrm{hlm} .88-89$ 
menyingkirkan peraturan atau ketentuan umum. Inilah yang juga diberlakukan dalam sistem pemidanaan. Artinya pembaharuan di bidang hukum pidana materiil yang selama ini telah dilakukan adalah bentuk penyesuaian, menambah maupun mengurangi KUHP yang telah ada maupun dengan mengeluarkan Undang-undang Pidana di luar KUHP karena perkembangan kriminalitas. ${ }^{11}$

Penjatuhan pidana kepada pelaku tindak pidana baik yang telah menyimpang dari KUHP maupun Undang-undang Pidana di luar KUHP tidak semata-mata sebagai bentuk pembalasan atau penderitaan namun pemidanaan terhadap seseorang pembuat diharapkan akan sangat mempengaruhi orang lain supaya tidak melakukan perbuatan yang sama. ${ }^{12}$

\section{Tindak pidana korupsi.}

Tindak pidana korupsi adalah perkara-perkara pidana yang menyangkut keuangan negara atau daerah atau badan hukum lainnya yang mempergunakan modal ndan atau kelonggaran-kelonggaran lainnya dari negara atau masyarakat atau yang bersangkuutan berkedudukan pelaku pidana. ${ }^{13}$ Rumusan tindak pidana korupsi dapat dibedakan menjadi dua, yang pertama tindak pidana korupsi yang merugikan keuangan atau perekonomian negara, ini disebutkan sebagai inti tindak pidana korupsi, dan tindak pidana yang berhubungan dengan penyelenggara negara. ${ }^{14}$

Korupsi di Indonesia telah terjadi secara sistematis dan meluas dalam kehidupan masyarakat, praktik korupsi yang terjadi secara meluas dan sistematis dapat membawa bencana bagi kehidupan mayarakat dan juga merupakan pelanggaran terhadap hak-hak sosial dan hak-hak ekonomi masyarakat. ${ }^{15}$ Huntington menyebutkan bahwa korupsi adalaaaah perilaku menyimpang dari public official atau pegawai negeri dari normanorma yang diterima dan dianut oleh masyarakat dengan tujuan untuk memperoleh keuntungan-keuntungan pribadi. ${ }^{16}$ Sedangkan menurut Bambang Poernomo sebagaimana diutip oleh Rudi Pardede, korupsi adalah : ${ }^{17}$

a. Memperkaya diri sendiri atau orang lain atau suatu badan hukum yang secara langsung atau tidak langsung diketahui atau patut disangka sapat merugikan keuangan negara.

b. Menguntungkan diri sendiri atau orang lain atau suatu badan dengan menyelahgunakan kewenangan karena jabatan atau kedudukan yang secara

11 Niniek Suparni, Eksisitensi Pidana Denda Dalam Sistem Pidana Dan Pemidanaan, (Jakarta: Sinar Grafika, 2007), hlm. 32.

${ }^{12} \mathrm{Ibid}, \mathrm{hlm} .18$.

${ }^{13}$ Prayitno Iman Sentosa, Pertanggungjawaban Tindak Pidana Korupsi Menurut Ajaran Dualitis, (Bandung: ALUMNI, 2015), hlm.121.

${ }^{14}$ Ibid.

15 Bambang Waluyo, Pemberantasan Tindak Pidana Korupsi (Strategi dan Optimalisasi), (Jakarta: Sinar Grafika, 2016), hlm.20.

${ }^{16}$ Chaerudin et al, Strategi Pencegahan dan Penegakan Hukum Tindak Pidana Korupsi, (Bandung: Refika Aditama, 2009), hlm.2.

17 Rusdi Pardede, Proses Pengembalian Kerugian Negara Akibat Korupsi, (Yogyakarta: GENTA Publishing, 2016), hlm.15-16. 
langsung atau tidak langsung dapat merugikan keuangan atau perekonomian negara.

c. Kejahatan tertentu dalam KUHP yang menyangkut kekuasaan umum, pekerjaan pembangunan, penggelapan atau pemerasan yang berhubungan dengan jabatan.

d. Memberikan hadiah atau janji kepada pegawai negeri sipil dengan mengingat suatu kekuasaan atau kewenangan yang melekat pada jabatan atau kedudukannya.

e. Tidak melapor setelah menerima pemberian atau janji kepada yang berwajib dalam waktu yang sesingkat-singkatnya tanpa alasan yang wajar sehubungan dengan kejahatan jabatan.

Jenis-jenis tindak pidana korupsi dalam UU Pemberantasan Tipikor dikelompokkan menjadi 7 (tujuh) jenis tindak pidana korupsi, yaitu :

1. Tindak pidana korupsi yang terkait dengan kerugian keungan negara atau perekonomian negara ( Pasal 2 dan 3)

2. Tindak pidana korupsi yang terkait suap menyuap ( Pasal 5 ayat (1) huruf a dan b, Pasal 5 ayat (2), Pasal 6 ayat (1) huruf a dan b, Pasal 6 ayat (2), Pasal 11, Pasal 12 huruf a dan b, Pasal 12 huruf $\mathrm{c}$ dan serta Pasal 13);

3. Tindak pidana korupsi yang terkait dengan penggelapan dalam jabatan ( Pasal 8, Pasal 9, Pasal 10 huruf a, b dan c);

4. Tindak pidana korupsi yang terkait dengan pemerasan ( Pasal 12 huruf e, $\mathrm{f}$ dan g);

5. Tindak pidana korupsi yang terkait dengan perbuatan curang ( Pasal 7 ayat (1) huruf a, b, c dan d, Pasal 7 ayat (2) dan Pasal 12 huruf b);

6. Tindak pidana korupsi yang terkait dengan benturan kepentingan dalam pengadaan ( Pasal 12 huruf i);

7. Gratifikasi sebagai salah satu bentuk tindak pidana korupsi ( Pasal 12 b dan Pasal 12 c).

\section{Tindak Pidana Pencucian Uang}

Memahami pengertian dan modus operandi tindak pidana pencucian uang telah dikriminalisasi di indonesia sejak tahun 2002 melalui Undang-Undang Nomor 15 Tahun 2002 tentang Tindak Pidana Pencucian Uang sebagaimana telah diubah dengan UndangUndang Nomor 25 Tahun 2003, telah disesuaikan dengan perkembangan kebutuhan penegakan hukum, praktik, dan standar internasional sehingga diganti dengan undangundang baru yang telah tertuang dalam Undang-Undang Republik Indonesia Nomor 8 Tahun 2010 tentang Pencegahan Dan Pemberantasan Tindak Pidana Pencucian Uang (UU Pencegahan dan Pemberantasan TPPU).

Berdasarkan penjelasan UU pencegahan dan pemberantasan TPPU tersebut bahwa pelaku tindak pidana berusaha menyembunyikan atau menyamarkan asal usul harta kekayaan yang merupakan hasil dari tindak pidana dengan berbagai cara agar harta kekayaan hasil tindak pidananya susah ditelusuri oleh aparat penegak hukum sehingga dengan leluasa memanfaatkan Harta Kekayaan tersebut baik untuk kegiatan yang sah maupun tidak sah. Karena itu, tindak pidana pencucian uang tidak hanya mengancam 
stabilitas dan integritas perekonomian dan sistem keuangan, tetapi juga dapat membahayakan sendi-sendi kehidupan bermasyarakat, berbangsa dan bernegara berdasarkan Pancasila dan Undang-Undang Dasar Negara Republik Indonesia Tahun 1945.

Kegiatan tindak pidana pencucian uang ini pada dasarnya dapat dikelompokkan pada tiga kegiatan, yakni : placement, layering dan integrtion ${ }^{18}$

1) Placement adalah sebuah tindakan dimana dana yang diperoleh dari hasil kejahatan ditempatkan atau disimpan didalam sistem keuangan, pada umumnya didalam sistem perbankan. Didalam proses placement terdapat pergerakan fisik uang.

2) Layering adalah modus dimana pihak pemilik dana melakukan berbagai macam tindakan untuk mengaburkan kepemilikan atas dana pada rekeningnya. Biasanya pada modus ini pihak pemilik dana ( beneficial owner) akan memerintahkan kepada pihak Penyedia Jasa Keuangan (Bank) untuk melakukan pemindahan dana kepada beberapa rekening dibank lain atau penyedia Jasa Keuangan lainnya baik dengan menggunakan nama si pemilik sendiri ataupun juga nama yang berbeda ( nomince selaku registered ownership). Kegiatan layering juga dapat dilakukan dengan mengubah bentuk harta hasil kejahatan menjadi bentuk harta yang lain tanpa melalui bentuan perbankan.

3) Integration adalah tahap akhir dimanapelaku tindak kejahatan menarik/ menggunakan harta yang telah di placement atau layering bagi kepentingan yang diinginkannya ataupun menggabungkan harta hasil kekayaan dengan harta kekayaannya yang sah.

Tindak Pidana Pencucian Uang sebagai suatu kejahatan mempunyai ciri khas tindak pidana pencucian uang bukan merupakan merupakan kajahatan tunggal melainkan kejahatan ganda. Tindak pidana pencucian uang sebagai kejahatan yang bersifat follow up crime atau kejahatan lanjutan, sedangkan kejahatan utamanya atau kejahatan asalnya disebut sebagai predicate offense atau core crime yaitu kejahatan asal yang menghasilkan uang yang kemudian dilakukan proses pencucian. Proses pencucian ini menyebabkan seolah-olah uang dari hasil kejahatan ini merupakan uang yang halal/ bersih.

Berdasarkan ketentuan Pasal 1 angka (1) UU Pencegahan dan Pemberantasan TPPU menentukan bahwa pencucian uang adalah segala perbuatan yang memenuhi unsur-unsur tindak pidana sesuai dengan ketentuan dalam undang-undang tersebut. Unsur-Unsur yang dimaksud adalah adalah unsur pelaku, unsur perbuatan melawan hukum dan unsur merupakan hasil tindak pidana.

Harta kekayaan yang dikualifikasikan sebagai harta kekayaan hasil tindak pidana yag tertuang dalam Pasal 2 ayat (2) UU Pencegahan dan Pemberantasan TPPU adalah harta yang berasal dari kejahatan seperti : korupsi, penyuapan, narkotika, psikotropika, penyeludupan tenaga kerja, penyeludupan migran, dibidang perbankan, dibidang pasal modal, bidang asuransi, kepabeanan, cukai dan perdagangan orang, perdagangan senjata

${ }^{18}$ Yenti Gernasih, Kriminalisasi Pencucian Uang (Money Laundering), (Jakarta : Program Pascasarjana Fakultas Hukum Universitas Indonesia, 2003), hlm.55. 
gelap, terorisme, penculikan, pencurian, penggelapan, penipuan, pemalsuan uang, perjudian, prostitusi, bidang perpajakan, bidang lingkungan hidup, bidang kehutanan, bidang kelautan dan perikanan serta tindak pidana lain yang diancam hukuman 4 tahun penjara yang dilakukan diwilayah Negara Kesatuan Republik Indonesia atau diluar wilayah Negara Kesatuan Republik Indonesia dan tindak pidana tersebut juga merupakan tindak pidana menurut hukum Indonesia.

Unsur-unsur perbuatan tindak pidana pencucian uang sebagai tahapan pencucian uang, tertuang dalam Pasal 3, Pasal 4, dan Pasal 5 UU Pencegahan dan Pemberantasan TPPU, adalah sebagai berikut :

a. Pasal 3

"Setiap orang yang menempatkan, mentransfer, mengalihkan, membelanjakan, membayarkan, menghibahkan, menitipkan, membawa keluar negeri, mengubah bentuk, menukarkan dengan mata uang atau surat berharga atau perbuatan lain atas harta kekayaan yang diketahuinya ataupun patut diduganya merupakan hasil tindak pidana sebagaimana dimaksud dalam Pasal 2 ayat (1) dengan tujuan menyembunyikan atau menyamarkan asal usul harta kekayaan dipidana kerena tindak pidana pencucian uang..."

b. Pasal 4

"Setiap orang yang menyembunyikan atau menyamarkan asal usul, sumber, lokasi, peruntukan, pengalihan hak-hak, atau kepemilikan yang sebenarnya yang atas harta kekayaan yang diketahuinya atau patut diduganya merupakan hasil tindak pidana sebagaimana dimaksud dalam pasal 2 ayat (1) dipidana karena tindak pidana pencucian uang..."

c. Pasal 5

"Setiap orang yang menerima atau menguasai penempatan, pentransferan, pembayaran, hibah, sumbangan, penitipan, pertukaran, atau menggunakan harta kekayaan yang diketahuinya atau patut diduganya merupakan hasil tindak pidana sebagaimana dimaksud dalam Pasal 2 ayat (1). Tidak berlaku bagi pihak pelapor yang melaksanakan kewajiban pelaporan..."

\section{Tindak Pidana Pendanaan Pemilihan Umum}

Berdasarkan Pasal 22 E Undang-Undang Dasar Republik Indonesia 1945 sebagai dasar hukum pelaksanaan Pemilihan Umum di Indonesia, menyebutkan bahwa pemilihan umum yaitu :

1) Pemilihan umum dilaksanakan secara langsung, umum, bebas, rahasia, jujur, dan adil setiap lima tahun sekali.

2) Pemilihan umum diselenggarakan untuk memilih anggota Dewan Perwakilan Rakyat, Dewan Perwakilan Daerah, Presiden dan Wakil Presiden dan Dewan Perwakilan Rakyat Daerah.

3) Perserta pemilihan umum untuk memilih anggota Dewan Perwakilan Rakyat dan anggota Dewan Pewakilan Rakyat Daerah adalah partai politik

4) Peserta pemilihan umum untuk memilih anggota Dewan Perwakilan Daerah adalah perseorangan.

5) Pemilihan umum diselelnggarakan oleh sutau komisi pemilihan umum yang bersifat nasional, tetap dan mandiri. 
6) Ketentuan berlanjut tentang pemilihan umum diatur dengan undang-undang.

Pemilihan umum menurut Pasal 1 angka 1 UU Pemilu adalah sarana kedaulatan rakyat untuk memilih anggota Dewan Perwakilan Rakyat, anggota Dewan Perwakilan Daerah, Presiden dan Wakil Presiden, dan untuk memilih anggota Dewan Perwakilan Rakyat, yang dilaksanakan secara langsung, umum, bebas, rahasia, jujur, dan adil dalam negara kesatuan republik indonesia berdasarkan Pancasila dan Undang-Undang Dasar Negara Republik Indonesia Tahun 1945.

Tindak pidana pemilihan umum menurut Pasal 1 angka (2) Peraturan Mahkamah Agung Nomor 1 Tahun 2018 tentang Tata Cara Penyelesaian Tindak Pidana Pemilihan dan Pemilihan Umum adalah tindak pidana pelanggaran dan/ atau kejahatan sebagaimana diatur dalam UU Pemilu. Perbuatan/ tindakan yang dapat dinilai sebagai tindak pidana pemilu adalah perbuatan yang dikriminalisasi berdasarkan Undang-Undang pemilu. Sesuai defenisi itu, juga dapat dipahami bahwa tindak pidana pemilu adalah pelanggaran terhadap suatu kewajiban, hal mana pelanggaran tersebut diancam sanksi pidana dalam UU Pemilu. ${ }^{19}$

Perbuatan-perbuatan yang dapat digolongkan sebagai tindak pidana pemilihan umum diatur dalam Bab II tentang Ketentuan Pidana Pemilihan Umum, dimulai dari Pasal 488 s.d Pasal 554 UU Pemilu. Beberapa pasal mengenai jenis-jenis tindak pidana pemilihan umum yang berkaitan dengan dana kampanye yang merupakan bagian dari Pasal 488 s.d Pasal 554 UU Pemilu, diantaranya yaitu memberikan keterangan tidak benar dalam laporan dana kampanye pemilu, yakni :

a. Pasal 489

"Peserta pemilu yang dengan sengaja memberikan keterangan tidak benar dalam laporan dana kampanye pemilu sebagaimana dimaksud dalam pasal 334 ayat (1), ayat (2), dan / atau ayat (3) serta Pasal 335 (1), ayat (2) dan/ atau ayat (3) dipidana ..."

b. Pasal 597

"Setiap orang yang dengan sengaja memberikan keterangan tidak benar dalam laporan dana Kampanye, dipidana ..."

c. Pasal 519

"Setiap orang yang dengan sengaja melakukan perbuatan curang untuk menyesatkan seseorang, dengan memaksa, dengan menjanjikan atau dengan memberikan uang atau materi yang lainnya untuk memperoleh dukungan bagi pencalonan anggota DPD dalam pemilu sebagaimana dimaksud dalam Pasal 183 dipidana ..."

d. Pasal 523

1) "Setiap pelaksana, peserta, dan/ atau tim Kampanye Pemilu yang dengan sengaja menjanjikan atau memberikan uang atau materi lainnya sebagai imbalan kepada peserta Kampanye Pemilu secara langsung ataupun tidak langsung sebagaimana dimaksud dalam Pasal 280 ayat (1) huruf j dipidana ..."

${ }^{19}$ Topo Santoso, dkk, Penegakan Hukum Pemilu, Praktik Pemilu 2014, Kajian Pemilu 20092014, (Jakarta: Perkumpulan Untuk Pemilu dan Demokrasi, 2006), hlm.89. 
2) "Setiap pelaksana, peserta, dan/ atau tim Kampanye Pemilu yang dengan sengaja pada Masa Tenang menjanjikan atau memberikan imbalan atau uang atau materi lainnya kepada pemilih secara langsung maupun tidak langsung sebagaimana dimaksud dalam Pasal 278 ayat 2 (dua) dipidana ..."

3) "Setiap orang yang dengan sengaja pada hari pemungutan suara menjanjikan atau memberikan uang atau materi lainnya kepada pemilih untuk tidak menggunakan hak pilihnya atau memilih peserta pemilu tertentu dipidana ..."

e. Pasal 525

1) "Setiap orang, kelompok, perusahaan, dan/ atau badan usaha nonpemerintah yang memberikan dana Kampanye Pemilu melebihi batas yang ditentukan sebagaimana dimaksud dalam pasal 327 ayat (1) dan Pasal 331 ayat (1) dipidana ..."

2) "Setiap peserta pemilu yang menggunakan kelebihan sumbangan, yang tidak melaporkan kelebihan sumbangan kepada KPU, dan/ atau tidak menyerahkan kelebihan sumbangan kepada kas negara paling lambat 14 (empa belas) hari setalah masa Kampanye Pemilu berakhir dipidana ..."

f. Pasal 526

1) "Setiap orang, kelompok, perusahaan, dan/ atau badan usaha nonpemerintah yang memberikan dana Kampanye Pemilu melebihi batas yang ditentukan sebagaimana dimaksud dalam Pasal 333 ayat (1) dipidana ..."

2) "Setiap peserta pemilu yang menggunakan kelebihan sumbangan, tidak melaporkan kelebihan sumbangan kepada KPU, dan/ atau tidak menyerahkan kelebihan sumbangan kepada kas negara paling lama 14 (empat belas) hari setalah masa Kampanye Pemilu berakhir sebagaimna dimaksud dalam Pasal 333 ayat (2) dipidana ..."

g. Pasal 527

"Peserta pemilu yang terbukti menerima sumbangan dana Kampanye Pemilu sebagaimana dimaksud dalam Pasal 339 (1) dipidana ..."

h. Pasal 528

1) "Peserta pemilu yang menerima sumbangan sebagaimana dimaksud dalam Pasal 339 ayat (2) dan tidak melaporkan kepada KPU dan/ atau tidak menyetorkan kepada kas negara, dipidana ..."

2) "Pelaksana dan tim kampanye yang menggunakan dana dari sumbangan yang dilarang dan/ atau tidak melaporkan dan/ atau tidak menyetorkan kepada kas negara sesuai dengan batas waktu yang ditentukan sebagaimana dimaksud dalam pasal 339 ayat (2), dipidana ..."

i. Pasal 548

"Setiap orang yang menggunakan anggaran pemerintah, pemerintah daerah, badan usaha milik negara, badan usaha milik daerah (BUMD), pemerintah desa atau sebutan lain dan badan usaha milik desa untuk disumbangkan atau diberikan kepada pelaksana kampanye sebagaimana dimaksud dalam pasal 339 ayat (4), dipidana ..."

j. Pasal 554

"Dalam hal penyelenggara pemilu melakukan tindak pidana pemilu sebagaimana dimaksuda dalam Pasal 488, Pasal 491, Pasal 492, Pasal 500, Pasal 504, Pasal 509, Pasal 510, Pasal 511, Pasal 518, Pasal 520, Pasal 523, Pasal 525 ayat (1), Pasal 526 (1), Pasal 531, Pasal 532, Pasal 533, Pasal 534, Pasal 535, dan Pasal 
536, pidana bagi yang bersangkutan ditambah $1 / 3$ (satu pertiga) dari ketentuan pidana yang ditetapkan dalam Undang-Undang ini."

\section{Urgensi Dilakukannya Rekonstruksi Sistem Pemidanaan Pelaku Tindak Pidana Korupsi Dan Pencucian Uang Dalam Pendanaan Pemilihan Umum}

Maraknya pelaku tindak pidana korupsi dan pencucian uang dalam pendanaan pemilihan umum diawali dengan adanya data statistik Tindak Pidana Korupsi berdasarkan jenis perkara yang dikeluarkan oleh Komisi Pemberantasan Korupsi pada tanggal 31 Desember 2019 sebagaimana tabel di bawah ini: ${ }^{20}$

\begin{tabular}{|c|c|c|c|c|c|c|c|}
\hline Perkara & $\begin{array}{c}\text { Pengadaan } \\
\text { Barang/Jasa }\end{array}$ & Perijinan & Penyuapan & Pungutan & $\begin{array}{c}\text { Penyalahgunaan } \\
\text { Anggaran }\end{array}$ & TPPU & $\begin{array}{c}\text { Meringtangi } \\
\text { Proses KPK }\end{array}$ \\
\hline 2004 & 2 & 0 & 0 & 0 & 0 & 0 & 0 \\
\hline 2005 & 12 & 0 & 7 & 0 & 0 & 0 & 0 \\
\hline 2006 & 8 & 5 & 2 & 7 & 5 & 0 & 0 \\
\hline 2007 & 14 & 1 & 4 & 2 & 3 & 0 & 0 \\
\hline 2008 & 18 & 3 & 13 & 3 & 10 & 0 & 0 \\
\hline 2009 & 16 & 1 & 12 & 0 & 8 & 0 & 0 \\
\hline 2010 & 16 & 0 & 19 & 0 & 5 & 0 & 0 \\
\hline 2011 & 10 & 0 & 25 & 0 & 4 & 0 & 0 \\
\hline 2012 & 8 & 0 & 34 & 0 & 3 & 2 & 2 \\
\hline 2013 & 9 & 3 & 50 & 1 & 0 & 7 & 0 \\
\hline 2014 & 15 & 5 & 20 & 6 & 4 & 5 & 3 \\
\hline 2015 & 14 & 1 & 38 & 1 & 2 & 1 & 0 \\
\hline 2016 & 14 & 1 & 79 & 1 & 1 & 3 & 0 \\
\hline 2017 & 15 & 2 & 93 & 0 & 1 & 8 & 2 \\
\hline 2018 & 9 & 0 & 78 & 0 & 0 & 4 & 2 \\
\hline 2019 & 11 & 0 & 49 & 1 & 2 & 0 & 0 \\
\hline
\end{tabular}

Berdasarkan tabel tersebut di atas menunjukkan bahwa sejak tahun 2012 tindak pidana pencucian uang menjadi salah satu jenis tindak pidana yang berkaitan dengan tindak pidana korupsi yang mana setiap tahunnya memiliki angka meskipun masih relatif kecil dibandingkan dengan tindak pidana yang lainnya. Hal ini berkembang dan menjadi peluang bagi pelaku kejahatan untuk menggunakan hasil tindak pidana korupsi menjadi sumber pendanaan pemilihan umum sebagai modus tindak pidana pencucian uang.

Pemidanaan bagi pelaku tindak pidana pemilu dalam bentuk pendanaan pemilu yang berasal dari tindak pidana korupsi dengan melihat masing-masing komponen dalam sistem hukum secara langsung berpengaruh kepada penegakan hukum. Lawrence M. Friedman menilai, berhasil atau tidaknya hukum ditegakkan tergantung kepada tiga kompnen sistem hukum.

${ }^{20} \mathrm{https}$ ://www.kpk.go.id/id/statistik/penindakan/tpk-berdasarkan-jenis-perkara?, diakses pada tanggal 2 Juni 2020, pukul 11.00 WIB 
Pertama, substansi hukum (legal substance). Substansi hukum adalah aturan, norma, dan pola perilaku nyata manusia yang berada dalam sistem pemilu itu. ${ }^{21} \mathrm{Kedua}$, struktur hukum (legal structure) atau struktur sistem hukum. Lawrence M. Friedman menyebutnya sebagai kerangka atau rangka atau bagian yang tetap bertahan atau bagian yang memberi semacam bentuk dan batasan terhadap keseluruhan. ${ }^{22}$ Keberadaan struktur hukum snagat penting, karena betapun bagusnya norma hukuum, namun jika tidak ditopang dengan aparat penegak hukum yang baik, penegakan hukum dan keadilan hanya sia-sia. Ketiga, budaya hukum ( legal culture ). Kultur hukum adalm opini-opini, kepercayaan-kepercayaan-kepercayaan ( Keyakinan-keyakinan), Kebiasaan-kebiasaan, cara berfikir, dan cara bertindak, baik dari para penegak hukum maupun dari warga masyarakat tentang hukum dan berbagai fenomena yang berkaitan dengan hukum maupun dari warga masyarakat tentang hukum dan berbagai fenomena yang berkaitan dengan hukum. ${ }^{23}$

Menurut Open Society korupsi pemilu adalah praktek pendanaan kempanye baik penerimaan maupun pengeluaran yang menciptakan hubungan koruptif antara penyumbang dan partai politik atau kandidat yang didukungnya maupun pola perilaku koruptif yang terjadi antara peserta pemilu dan voters. Jadi secara umum ada tiga bentuk korupsi pemilu yaitu $:^{24}$

a. Manipulasi pengumpulan dan pencatatan dana kampanye, partai politik atau kandidat menerima donasi dari sumber-sumber yang dilarang oleh aturan seperti sumbangan melebihi batas maksimal, bersumber dari hasil korupsi atau kejahatan, dan penyumbang tidak jelas.

b. Penyelahgunaan sumber dana dan daya negara

Partai politik atau kandidat menyelahgunakan sumber dana dan daya negara/ publik untuk kepentingan pemenangan mereka.

c. Politik uang

Partai, kandidat, tim sukses, memberikan/ menjajikan uang atau barang kepada pemilih atau penyelenggara pemilihan dalam rangka memenangkan pemilu.

Hasil dari tindak pidana korupsi yang dipergunakan dalam pendanaan pemilihan umum merupakan unsur tindak pidana pencucian uang. Ketiga tindak pidana tersebut yakni tindak pidana korupsi, tindak pidana pemilihan umum dan tindak pidana pencucian uang dalam masing-masing undang-undang yang merupakan tindak pidana khusus, diluar ketentuan Kitab Undang-Undang Hukum Pidana (KUHP). Ketiga undang-undang tersebut adalah UU Pemberantasan Korupsi, UU Pencegahan dan Pemberantasan TPPU,

\footnotetext{
${ }^{21}$ Lawrence M. Friedman, American Law : An Introduction, Second Edition, Penerjemah : Wishu Basuki, (Jakarta: Tatanusa, 2001), hlm.7.

${ }^{22}$ Ibid, hlm. 12

${ }^{23}$ Achmad Ali, Menguak Teori Hukum (Legal Theory) dan Teori Peradilan ( Judicial prudence) Termasuk Interpretasi Undang-Undang (Legisprudence) Volume I, ( Jakarta: Kencana, 2012), hlm.204.

${ }^{24}$ Ade Irawan, dkk, Panduan Pemantauan Korupsi Pemilu, (Jakarta: Indonesia Corruption Warch, 2014), hlm.6.
} 
dan UU Pemilu yang secara umum pemidanaan pelaku tindak pidana korupsi, tindak pidana pemilihan umum maupun tindak pidana pencucian uang tersebut berdiri sendiri secara lex specialis.

Berdasarkan perbuatan-perbuatan yang dapat digolongkan sebagai tindak pidana Pemilihan Umum yang diatur mulai dari Pasal 488 s.d Pasal 554 UU Pemilu dalam Bab II tentang Ketentuan Pemilihan Umum, maka unsur-unsur tindak pidana pemilihan umum dalam pendanaan yang berkaitan dengan unsur-unsur tindak pidana korupsi diantaranya adalah :

\begin{tabular}{|c|c|c|c|}
\hline No. & Pasal & Unsur-unsur Tindak Pidana Korupsi & Sanksi Pidana \\
\hline 1 & Pasal 519 & $\begin{array}{l}\text { Dengan sengaja melakukan perbuatan curang } \\
\text { untuk menyesatkan seseorang, dengan memaksa, } \\
\text { dengan menjanjikan atau dengan memberikan } \\
\text { uang atau materi lainnya. }\end{array}$ & $\begin{array}{l}\text { Pidana penjara paling lama } 3 \\
\text { (tiga) tahun dan denda paling } \\
\text { banyak Rp. } 36.000 .000,00 \text { ( tiga } \\
\text { puluh enam juta rupiah) }\end{array}$ \\
\hline 2 & $\begin{array}{c}\text { Pasal } 523 \\
\text { Ayat } 1\end{array}$ & $\begin{array}{l}\text { Dengan sengaja memberikan atau memberikan } \\
\text { uang atau materi lainnya sebagai imbalan kepada } \\
\text { peserta Kampanye Pemilu secara langsung } \\
\text { ataupun tidak langsung }\end{array}$ & $\begin{array}{l}\text { Pidana penjara paling lama } 2 \\
\text { (dua) tahun dan denda paling } \\
\text { banyak Rp. } 24.000 .00,00 \text { (dua } \\
\text { puluh empat juta rupiah) }\end{array}$ \\
\hline 3 & $\begin{array}{l}\text { Pasal } 523 \\
\text { Ayat } 2\end{array}$ & $\begin{array}{l}\text { Dengan sengaja pada Masa tenang menjanjikan } \\
\text { atau memberikan imbalan uang atau materi } \\
\text { lainnya kepada Pemilih secara langsung atau tidak } \\
\text { langsung }\end{array}$ & $\begin{array}{l}\text { Pidana penjara paling lama } 4 \\
\text { (empat) tahun dan denda paling } \\
\text { banyak } \\
\text { (empat puluh delapan juta } \\
\text { rupiah) }\end{array}$ \\
\hline 4 & $\begin{array}{c}\text { Pasal } 523 \\
\text { Ayat } 3\end{array}$ & $\begin{array}{l}\text { Dengan sengaja pada hari pemungutan suara } \\
\text { menjanjikan atau memberikan uang atau matteri } \\
\text { lainnya kepada pemilih untuk tidak menggunakan } \\
\text { hak pilihnya atau memilih Peserta Pemilu } \\
\text { Tertentu }\end{array}$ & $\begin{array}{l}\text { Pidana penjara paling lama } 3 \\
\text { (tiga) tahun dan denda paling } \\
\text { banyak Rp. } 36.00 .000,00 \text { (tiga } \\
\text { puluh enam juta rupiah) }\end{array}$ \\
\hline 5 & Pasal 527 & $\begin{array}{l}\text { Terbukti menerima sumbangan dana Kampanye } \\
\text { Pemilu sebagaimana dimaksud Pasal } 339 \text { ayat (1) }\end{array}$ & $\begin{array}{l}\text { Pidana penjara paling lama } 3 \\
\text { (tiga) tahun dan denda paling } \\
\text { banyak Rp. } 36.000 .000,00 \text { (tiga } \\
\text { puluh enam juta rupiah) }\end{array}$ \\
\hline 6 & $\begin{array}{c}\text { Pasal } 528 \\
\text { Ayat } 1\end{array}$ & $\begin{array}{l}\text { Menerima sumbangan sebagaimana dimaksud } \\
\text { dalam pasal } 339 \text { ayat (2) dan tidak melaporkan } \\
\text { kepada KPU dan/ atau tidak menyetorkan ke kas } \\
\text { negara }\end{array}$ & $\begin{array}{l}\text { Pidana penjara paling lama } 4 \\
\text { (empat) tahun dan denda } \\
\text { sebanyak } 3 \text { (tiga) kali dari } \\
\text { sumbangan yang diterima }\end{array}$ \\
\hline
\end{tabular}




\begin{tabular}{|c|c|c|c|}
\hline 7 & $\begin{array}{c}\text { Pasal } 528 \\
\text { Ayat } 2\end{array}$ & $\begin{array}{l}\text { Menggunakan dana dari sumbangan yang } \\
\text { dilarang dan/ atau tidak melaporkan dan/ atau } \\
\text { tidak menyetorkan ke kas negara sesuai dengan } \\
\text { batas waktu yang ditentukan sebagaimana } \\
\text { dimaksud dalam Pasal } 339 \text { ayat (2) }\end{array}$ & 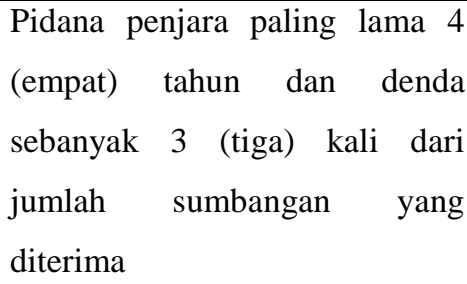 \\
\hline 8 & Pasal 548 & $\begin{array}{l}\text { Menggunakan anggaran pemerintah, pemerintah } \\
\text { daerah, badan usaha milik negara, badan usaha } \\
\text { milik daerah (BUMD), pemerintah desa atau } \\
\text { sebutan lain dan badan usaha milik desa untuk } \\
\text { disumbangkan atau diberikan kepada pelaksana } \\
\text { kampanye sebagaimana dimaksud dalam Pasal } \\
339 \text { ayat (4) }\end{array}$ & $\begin{array}{l}\text { Pidana penjara paling lama } 3 \\
\text { (tiga) tahun dan pidana denda } \\
\text { paling banyak } \\
1.000 .000 .000,00\end{array}$ \\
\hline
\end{tabular}

Dari 8 (delapan) pasal dalam UU Pemilu tersebut diatas maka terdapat unsurunsur tindak pidana korupsi yang terkait suap menyuap dan gratifikasi, yakni perbuatan yang berupa:

a) Perbuatan curang untuk menyesatkan seseorang, dengan memaksa, dengan menjanjikan atau dengan memberikan uang atau materi lainnya;

b) Menjanjikan atau memberikan uang atau materi lainnya sebagai imbalan;

c) Menjanjikan atau memberikan imbalan uang atau materi lainnya (pada masa tenang);

d) Menjanjikan atau memberikan uang atau materi lainnya (pada hari pemungutan suara);

e) Menerima sumbangan dana Kampanye Pemilu;

f) Menerima sumbangan dan tidak melaporkan kepada KPU dan/ atau tidak menyetokan ke kas negara;

g) Menggunakan dana dari sumbangan yang dilarang dan/ atau tidak melaporkan dan/ atau tidak menyetorkan ke kas negara;

h) Menggunakan anggaran pemerintah, pemerintah daerah, badan usaha milik negara, badan usaha milik daerah, pemerintah desa atau sebutan lain dan badan usaha miliik desa.

UU Pemilu sebagai Lex Specialis dari KUHP telah menentukan tersendiri saanksi pidana terhadap perbuatan-perbuatan yang menyerupai unsur-unsur tindak pidana korupsi berupa suap atau gratifikasi. Sanksi pidana yang diberikan berupa pidana penjara dengan maksimal hanya 4 (empat) tahun, untuk pidana denda paling banyak $\mathrm{Rp}$. 1.000.000.000,00 (satu miliar rupiah) atau denda sebanyak 3 (tiga) kali dari jumlah sumbangan yang diterima.Namun dalam sanksi pidana bagi tindak pidana korupsi berupa suap dalam UU Pemberantasan Tipikor ditentukan pidana penjara paling singkat 1 (satu) tahun dan paling lama 5 (lima) tahun dan atau pidana denda paling sedikit Rp. 50.000.000,00 ( lima puluh juta rupiah) dan paling banyak Rp. 250.000.000,00 (dua ratus 
lima puluh juta rupiah) ataupun gratifikasi berupa pidana penjara seumur hidup atau pidana penjara paling singkat 4 (empat) tahun dan paling lama 20 (dua puluh) tahun dan pidana denda paling sedikit Rp. 2000.000.000,00 (dua ratus juta rupiah) dan paling banyak Rp. 1.000.000.000,00 (satu miliar rupiah).

Ketika setiap orang melakukan perbuatan salah satu atau lebih dari satu perbuatan dari 8 (delapan) pasal dalam UU Pemilu tersebut diatas, dan terbukti pendanaan tersebut berasal dari tindak pidana korupsi baik suap maupun gratifikasi, maka pemidanaan yang dijatuhkan hakim cenderung menggunakan ketentuan UU Pemberantasan Tipikor. Padahal terbukti bahwa pendanaan pemilihan umum tersebut berasal dari tindak pidana korupsi yang merupakan juga indikasi adanya unsur-unsur tindak pidana pencucian uang sebagaimana Pasal 2 ayat (2) UU Pencegahan dan Pemberantasan TPPU bahwa harta yang berasal dari kejahatan seperti korupsi.

Pemidanaan yang kerap kali diberikan adalah berasal dari sanksi/ ketentuan pidana salah satu dari undang-undang Lex Specialis tersebut, yakni UU Pemberantasan Tipikor atau UU Pemilu ataupun UU Pencegahan dan Pemberantasan TPPU. Bahkan UU Pencegahan dan Pemberantasan TPPU sangat jarang diberlakukan oleh penegak hukum pada kasus-kasus tindak pidana korupsi yang terbukti dipergunakan pelaku untuk pendanaan pemilihan umum. Penegak hukum lebih menggunakan UU Pemberantasan Tipikor karena terlebih dahulu adanya kegiatan Operasi Tangkap Tangan oleh Komisi Pemberantasan Korupsi.

Pada dasarnya adanya unsur-unsur tindak pidana pencucian uang ada kasus tindak pidana korupsi dalam pendanaan pemilihan umum dibuktikan dari adanya perbuatan menempatkan, mentransfer, mengalihkan, membelanjakan, membayarkan, menghibahkan, menitipkan, menyembunyikan atau menyamarkan asal usul, bahkan menerima atau menguasai penempatan, penstransferan, pembayaran, hibah, sumbangan, penitipan, penukaran atau menggunakan harta kekayaan atas uang hasil tindak pidana korupsi tersebut. Bahwa untuk pencucian uangnya adalah ditempatkannya hasil korupsi untuk pendanaan pemilihan umum atau dana kampanye sebagaimana bentuk perbuatan dari 8 (delapan) pasal dalam UU Pemilu tersebut diatas. Hal ini merupakan salah satu indikator yang menguatkan upaya penyembunyian asal-usul harta kekayaan hasil kejahatan korupsi serta mempersulit pelacakan para penegak hukum.

Sholehuddin berpandangan bahwa dalam kaitannya dengan masalah pemidanaan, maka yang dituntut oleh asas keseimbangan ini adalah pemidanaan itu harus mengakomodasi kepentingan masyarakat, pelaku dan juga korban. Pemidanaan tidak boleh hanya menekankan pada salah satu kepentingan. ${ }^{25}$ Pemidanaan itu sendiri merupakan proses paling kompleks dalam sistem peradilan pidana karena melibatkan banyak orang dan institusi yang berbeda. ${ }^{26}$

${ }^{25}$ Sholehuddin, Sistem Sanksi Dalam Hukum Pidana, (Jakarta: Raja Grafindo Persada, 2007), hlm.113.

${ }^{26}$ Ibid, hlm. 114. 
Masalah pemidanaan bagi pelaku tindak pidana korupsi dan pencucian uang dalam pendanaan pemillihan umum tidak dapat hanya mementingkan kepentingan pelaku, misalnya cukup dengan penjatuhan sanksi pidana sesuai dengan UU Pemberantasan Tipikor atau hanya UU Pemilu saja, namun seyogyanya mengacu kepada tujuan pemidanaan yaitu mencegah dilakukannya tindak pidana dengan menegakkan norma hukum demi pengayoman masyarakat dan menyelesaikan konflik yang ditimbulkan oleh tindak pidana, memulihkan keseimbangan, dan mendatangkan rasa damai dalam masyarakat.

Dampak korupsi dalam pemilu sangat banyak. Paling jelas, politisi yang terpilih dengan cara yang korupsi dipastikan melakukan praktek korupsi ketika berkuasa atau lebih mengutamakan kepentingan para donatur dibanding rakyat dengan memberikan banyak keistimewaan seperti proteksi dan imbalan proyek-proyek yang didanai oleh anggaran negara. ${ }^{27}$ Dampat tersebut setidaknya dapat diminimalisir dengan pemidanaan terhadap pelaku sesuai dengan tujuan pemidanaan.

Proses penanganan pelaku tindak pidana korupsi berjalan sesuai dengan ketentuan UU Pemberantasan Tipikor, apabila ada indikasi hasil tindak pidana korupsi tersebut dipergunakan untuk pendanaan pemilihan umum maka proses penanganannya mengacu pada UU Pemilu tanpa harus menghentikan proses penanganan pelaku tindak pidana korupsi tersebut ataupun sebaliknya. Demikian pula untuk penanganan pelaku yang berindikasi terjadinya tindak pidana pencucian uang maka seharusnya tidak berhenti sampai pada proses penanganan perkara tindak pidana korupsi atau tindak pidana pemilihan umu saja namun tetap berlanjut penaganannya sesuai dengan UU Pencegahan dan Pemberantasan TPPU.

Pemidanaan terhadap pelaKu yang terbukti telah bertentangan dengan UU Pemberantasan Tipikor, UU Pemilu, dan UU Pencegahan dan Pemberantasan TPPU baik secara langsung/ tidak langsung secara berlanjut tidak terpisah dari surat dakwaan yang disampaikan secara kumulatif dengan perkara tindak pidana korupsi. Dalam hal ini, penegak hukum telah dapat mengidentifikasi dan membuktikan adanya suatu tindak pidana korupsi atas seluruh sebagian dari harta kekayaan yang dirampas. Sehingga terjadi pemberatan pidana bagi pelaku tindak pidana korupsi dan pencucian uang dalam pendanaan pemilihan umum.

\section{Penutup}

\section{Kesimpulan}

Pemidanaan pelaku tindak pidana korupsi dan pencucian uang dalam pendanaan pemilihan umum sejalan dengan tujuan pemidanaan yaitu mencegah dilakukannya tindak pidana dengan menegakkan norma hukum demi pengayoman masyarakat dan menyelesaikan konflik yang ditimbulkan oleh tindak pidana, memulihkan keseimbangan, dan mendatangkan rasa damai dalam masyarakat. Melalui pengenaan ketiga undang-

${ }^{27}$ Ade Irawan, dkk, Loc.Cit. 
Volume 15, Nomor 1, Januari-Juni 2020

undang yakni UU Pemberantasan Tipikor, UU Pemilu, dan UU Pencegahan dan Pemberantasan TPPU kepada pelaku tindak pidana korupsi dan pencucian uang dalam pendanaan pemilhan umum maka surat dakwaan harus disusun secara kumulatif. Hal ini berkenaan dengan bentuk pencucian pelaku tindak pidana korupsi dalam pendanaan pemilihan umum adalah ditempatkannya hasil korupsi untuk pendanaan pemilihan umum atau dana kampanye.

\section{Rekomendasi}

Rekonstruksi sistem pemidanaan pelaku tindak pidana korupsi dan pencucian uang dalam pendanaan pemilihan umum melibatkan para penegak hukum khususnya para penyidik dan lembaga khusus yang diberi kewenangan dalam penanganan ketiga tindak pidana tersebut, yakni sinergitas dalam penanganan dan penegakan hukum bagi pelaku.

\section{Daftar Pustaka}

\section{Buku :}

Ali, Achmad, Menguak Teori Hukum (Legal Theory) dan Teori Peradilan ( Judicial prudence) Termasuk Interpretasi Undang-Undang (Legisprudence) Volume I, Jakarta: Kencana, 2012

Bambang, Waluyo, Pemberantasan Tindak Pidana Korupsi (Strategi dan Optimalisasi), Jakarta: Sinar Grafika, 2016

Chaerudin et al, Strategi Pencegahan dan Penegakan Hukum Tindak Pidana Korupsi, Bandung: Refika Aditama, 2009

Friedman, Lawrence M., American Law : An Introduction, Second Edition, Penerjemah : Wishu Basuki, Jakarta: Tatanusa, 2001

Gernasih, Yenti, Kriminalisasi Pencucian Uang (Money Laundering), Jakarta : Program Pascasarjana Fakultas Hukum Universitas Indonesia, 2003

Husein, Yunus, "Pembangunan Rezim Anti Pencucian Uang Di Indonesia dan Implikasinya Terhadap Profesi Akuntan". Makalah Disampaikan Pada Forum Ekonomi Studi Akuntansi (Fiesta 2006) dan Temu Nasional Jaringan Masiswa Akuntansi Indonesia ( Tn-Jmai), Diselenggarakan Oleh Fakultas Ekonomi Universitas Bung Hatta, Di Padang, 8 Mei 2006.

Irawan, Ade dkk, Panduan Pemantauan Korupsi Pemilu, Jakarta: Indonesia Corruption Warch, 2014

Kartayasa, Mansur, Korupsi dan Pembuktian Terbalik dari Perspektif Kebijakan Legislasi dan Hak Asasi Manusia, Jakarta: Kencana, 2017

Pardede, Rudi, Proses Pengembalian Kerugian Negara Akibat Korupsi, Yogyakarta: GENTA Publishing, 2016 
Volume 15, Nomor 1, Januari-Juni 2020

Perencanaan Pembangunan Hukum Nasional Bidang Hukum Pidana dan Sistem Pemidanaan (Politik Hukum dan Pemidanaan ), Departemen Hukum dan Hak Asasi Manusia Badan Pembinaan Hukum Nasional Tahun 2008.

Santoso, Topo, dkk, Penegakan Hukum Pemilu, Praktik Pemilu 2014, Kajian Pemilu 2009-2014, Jakarta: Perkumpulan Untuk Pemilu dan Demokrasi, 2006

Santoso, Topo, Tindak Pidana Pemilu, (Jakarta: Sinar Grafika, 2016).

Sentosa, Prayitno Iman, Pertanggungjawaban Tindak Pidana Korupsi Menurut Ajaran Dualitis, Bandung: ALUMNI, 2015

Sjahdeini, Sutan Remy, Seluk Beluk Tindak Pidana Pencucian Uang dan Pembiayaan Terorisme, Jakarta : Grafiti, 2004

Sholehuddin, Sistem Sanksi Dalam Hukum Pidana, Jakarta: Raja Grafindo Persada, 2007

Suparni, Niniek, Eksistensi Pidana Denda Dalam Sistem Pidana Dan Pemidanaan, Jakarta: Sinar Grafika, 2007

Sutedi,Adrian, Tindak Pidana Pencucian Uang, Ctk. Pertama, Bandung: Citra Aditya Bakti, 2008

Tim Kompendium Hukum tentang Kerjasama Internasional Di Bidang Penegakan Hukum, Laporan Akhir Kompendium Hukum Tentang Kerjasama Internasional Di Bidang Penegakan Hukum, Badan Pembinaan Hukum Nasional Kementrian Hukum dan Ham RI, Jakarta, 2012

\section{Peraturan Perundang-Undangan :}

Undang-Undang Republik Indonesia Nomor 31 Tahun 1999 Sebagaimana telah diubah dengan Undang-Undang Republik Indonesia Nomor 20 Tahun 2001 tentang Pemberantasan Tindak Pidana Korupsi, Lembaran Negara Republik Indonesia Tahun 2001 Nomor 134, Tambahan Lembaran Negara Republik Indonesia Nomor 4150.

Undang-Undang Republik Indonesia Nomor 8 Tahun 2010 Tentang Pencegahan dan Pemberantasan Tindak Pidana Pencucian Uang, Lembaran Negara Republik Indonesia Tahun 2010 Nomor 122, Tambahan Lembaran Negara Republik Indonesia Nomor 5164.

Undang-Undang Republik Indonesia Nomor 7 Tahun 2017 tentang Pemilihan Umum, Lembaran Negara Republik Indonesia Tahun 2017 Nomor 182, Tambahan Lembaran Negara Republik Indonesia Nomor 6109. 